\title{
Myelodysplastic syndrome presenting with central diabetes insipidus is associated with monosomy 7, visible or hidden: report of two cases and literature review
}

\author{
Yunfan Yang, Ting Lin, Tian Dong and Yu Wu* (1)
}

\begin{abstract}
Background: Central diabetes insipidus (CDI) is a rare complication of myelodysplastic syndrome (MDS). Although the cytogenetic features of patients with MDS and CDI are not clear, CDI in patients with acute myeloid leukemia (AML) is associated with chromosome 7 and/or 3 anomalies.

Case presentation: In this report, we describe two patients with MDS and concurrent CDI, and in one of them, CDI was the first manifestation. One patient had monosomy 7 on metaphase cytogenetics (MC). Monosomy 7 and numerous cytogenetic abnormalities were found in the other patient using single-nucleotide polymorphism array (SNP-A) karyotyping, while the MC did not uncover monosomy 7. In this manuscript we also reviewed reported cases of MDS with diabetes insipidus (DI-MDS) to summarize the relationship between DI-MDS and karyotype, and explore the best treatment strategy for DI-MDS.
\end{abstract}

Conclusions: DI-MDS is closely related to monosomy 7. Allogeneic hematopoietic stem cell transplantation may be the only effective treatment for DI-MDS. The SNP-A-based karyotyping is helpful to reveal subtle cytogenetic abnormalities and unveil their roles in the clinical features of MDS.

Keywords: Myelodysplastic syndrome, Diabetes insipidus, Single-nucleotide polymorphism array, Monosomy 7

\section{Background}

Diabetes insipidus (DI) can be caused by either deficiency of antidiuretic hormone (ADH), known as central $\mathrm{DI}(\mathrm{CDI})$ or inadequate sensitivity of the kidney to $\mathrm{ADH}$, known as nephrogenic DI. CDI is rare in cases of hematological malignancy but can be the initial manifestation of acute myeloid leukemia (AML) and myelodysplastic syndrome (MDS) [1-4]. AML and MDS with DI (DIAML and DI-MDS) are closely related with cytogenetic abnormalities, including partial or complete deletion of

*Correspondence: wu_yu@scu.edu.cn

Department of Hematology, Institute of Hematology, West China Hospital of Sichuan University, Guoxuexiang 37, Chengdu 610041, People's

Republic of China chromosome 7 and structural abnormalities of chromosome 3 [4-8]. In this report, we described two cases of MDS and CDI. Monosomy 7 was found in both cases by metaphase cytogenetics (MC) and single-nucleotide polymorphism array (SNP-A)-based karyotyping. In addition, we reviewed all the DI-MDS reported in the literature, in order to provide experience for the diagnosis and treatment of similar cases.

\section{Case presentation \\ Case 1}

A 43-year-old man presented with a 6-month history of polydipsia and polyuria. His urine output was 3.5 to 6 L per day with a urine specific gravity of 1.003 (normal range, $1.010-1.025$ ). His serum sodium was $150.4 \mathrm{mmol} / \mathrm{l}$ original author(s) and the source, provide a link to the Creative Commons licence, and indicate if changes were made. The images or other third party material in this article are included in the article's Creative Commons licence, unless indicated otherwise in a credit line to the material. If material is not included in the article's Creative Commons licence and your intended use is not permitted by statutory regulation or exceeds the permitted use, you will need to obtain permission directly from the copyright holder. To view a copy of this licence, visit http://creativecommons.org/licenses/by/4.0/. The Creative Commons Public Domain Dedication waiver (http://creativeco mmons.org/publicdomain/zero/1.0/) applies to the data made available in this article, unless otherwise stated in a credit line to the data. 
(normal range, 137-147 $\mathrm{mmol} / \mathrm{l}$ ), urine osmolality $146 \mathrm{mOsm} / \mathrm{kg}$ (normal range, 50-1,200 $\mathrm{mOsm} / \mathrm{kg}$ ), and plasma osmolality $320 \mathrm{mOsm} / \mathrm{kg}$ (normal range, 275$305 \mathrm{mOsm} / \mathrm{kg}$ ). Thyroid-stimulating hormone (TSH) was elevated at $6.72 \mathrm{mU} / \mathrm{l}$ (normal range, $0.27-4.2 \mathrm{mU} / \mathrm{l}$ ), and prolactin was $23.64 \mathrm{ng} / \mathrm{ml}$ (normal range, 4.60-21.40 ng/ $\mathrm{ml})$. The levels of other pituitary hormones, testosterone, and the morning cortisol level were normal. Magnetic resonance imaging (MRI) revealed a slightly thickened pituitary stalk and a small nodule in the left pituitary gland. The water deprivation and vasopressin test supported the diagnosis of CDI. The patient was started on desmopressin and his symptoms began to get relieved.

The complete blood count $(\mathrm{CBC})$ showed a white blood cell count (WBC) of $2.81 \times 10^{9} / \mathrm{l}$, hemoglobin of $111 \mathrm{~g} / \mathrm{l}$, and platelet count of $34 \times 10^{9} / \mathrm{l}$. His bone marrow aspirate revealed dysplasia of the erythroid lineage with $6.5 \%$ myeloblasts. Flow cytometry and bone marrow biopsy demonstrated MDS. Standard molecular genetic analysis showed a single mutation of CEBPA, whereas FLT3ITD, NPM1, C-kit, IDH1, IDH2, DNMT3A, PHF6, TET2, ASXL1, and EVI1 were negative. Karyotype analysis of metaphase chromosomes was 47,XY,+8[10]. To confirm the karyotype and broaden the scope of karyotyping, a SNP-A-based analysis was performed by using the Affymetrix Gene Chip Mapping $750 \mathrm{~K}$ Assay kit and Gene Chip Scan 300D × V.2 (Affymetrix, Santa Clara, CA). Interestingly, SNP-A-based karyotyping revealed a complex karyotype (Fig. 1, Table 1) that included monosomy 7, 12p-, and trisomy 8 , which are common in myeloid malignancy, especially in MDS, and 4 short lesions were recognized as an absence of heterogeneity $(\mathrm{AOH})$ of uncertain significance. Thus, a diagnosis of MDS with excess blasts-1 (MDS-EB1) was established. The patient underwent peripheral blood stem cell transplantation (PBSCT) from a human leukocyte antigen (HLA)-matched-sibling donor. Oral desmopressin was successfully tapered off. He achieved complete remission 11 months after the transplant with no evidence of recurrent DI.

\section{Case 2}

A 40-year-old female presented with a 5-month history of dizziness and weakness. The $\mathrm{CBC}$ showed a WBC count of $1.16 \times 10^{9} / \mathrm{l}$, hemoglobin of $63 \mathrm{~g} / \mathrm{l}$, and platelet count of $51 \times 10^{9} / 1$. Bone marrow aspirate and flow cytometry analysis indicated MDS-RAEB1. Karyotype analysis revealed a complex karyotype of 46,XX,t (3;3)(q21;q26)[2]/45,idem,-7[4]/45,idem,der(4)
$(1 ; 4)(q 25 ; p 16),-7[11] / 46, X X[3] \quad$ (Fig. 2). Fluorescence in situ hybridization (FISH) of 5p15.2/5q33-34, 7p11.1q11.1/7q31, 8p11.1-q11.1, 20q12, 17p13.1 revealed a signal loss of 7p11.1-q11.1/7q31, which indicated -7 . Real-time fluorescence quantitative polymerase chain reaction revealed overexpression of EVI1 (EVI1/ ABL1 $=95.21 \%$ ). After hospitalization, the patient developed polydipsia and polyuria, and her urine output was 3 to $7 \mathrm{~L}$ per day with a urine specific gravity of 1.003 (normal range, 1.010-1.025). Her serum sodium and urine sodium were $152.5 \mathrm{mmol} / \mathrm{l}$ (normal range, $137-147 \mathrm{mmol} / \mathrm{l}$ ) and $177.3 \mathrm{mmol} / 24 \mathrm{~h}$ (normal range, 130-261 mmol/24 h), respectively. A brain MRI showed a normal pituitary gland. The endocrinology service was consulted, and CDI was diagnosed. She started on oral desmopressin with gradual relief in symptoms.

Subsequently, the patient was subjected to two cycles of decitabine-based chemotherapy without response, and progressed to AML quickly. She underwent PBSCT from an HLA-identical sibling donor, but remission was still not achieved. Interestingly, her symptoms of polydipsia and polyuria disappeared more than 1 month after hematopoietic stem cell transplantation (HSCT) and reappeared when the blasts increased 2 months after HSCT. The patient progressed to AML and finally died 8 months after the transplant.

\section{Discussion and conclusions}

We reported two cases of DI-MDS with monosomy 7. In the first case, CDI was the initial manifestation of MDS, which might have led to misdiagnosis or delayed treatment. MDS associated with DI has rarely been reported. To our knowledge, only five MDS cases with CDI have been reported till now $[4,6,7,9,10]$. The reported DIMDS cases are summarized in Table 2.

Although the reason why DI occurs in MDS is unclear, the co-occurrence of AML and DI has several possible explanations. Presumed causes include leukemic infiltration of the pituitary gland or hypothalamus, leukostasis, thrombosis, hemorrhage, and infection. In case 1, the MRI revealed a slightly thickened pituitary stalk and a small nodule in his left pituitary, which may indicate a pituitary infiltration. The WBC count of both patients was lower than normal, which makes leukostasis unlikely.

In our study, partial or complete monosomy of chromosome 7 was detected in both cases by MC analysis or SNP-based microarray. This abnormality was also found in 3 of 5 reported cases of DI-MDS $[4,6,10]$. One possible explanation for this correlation is that monosomy 


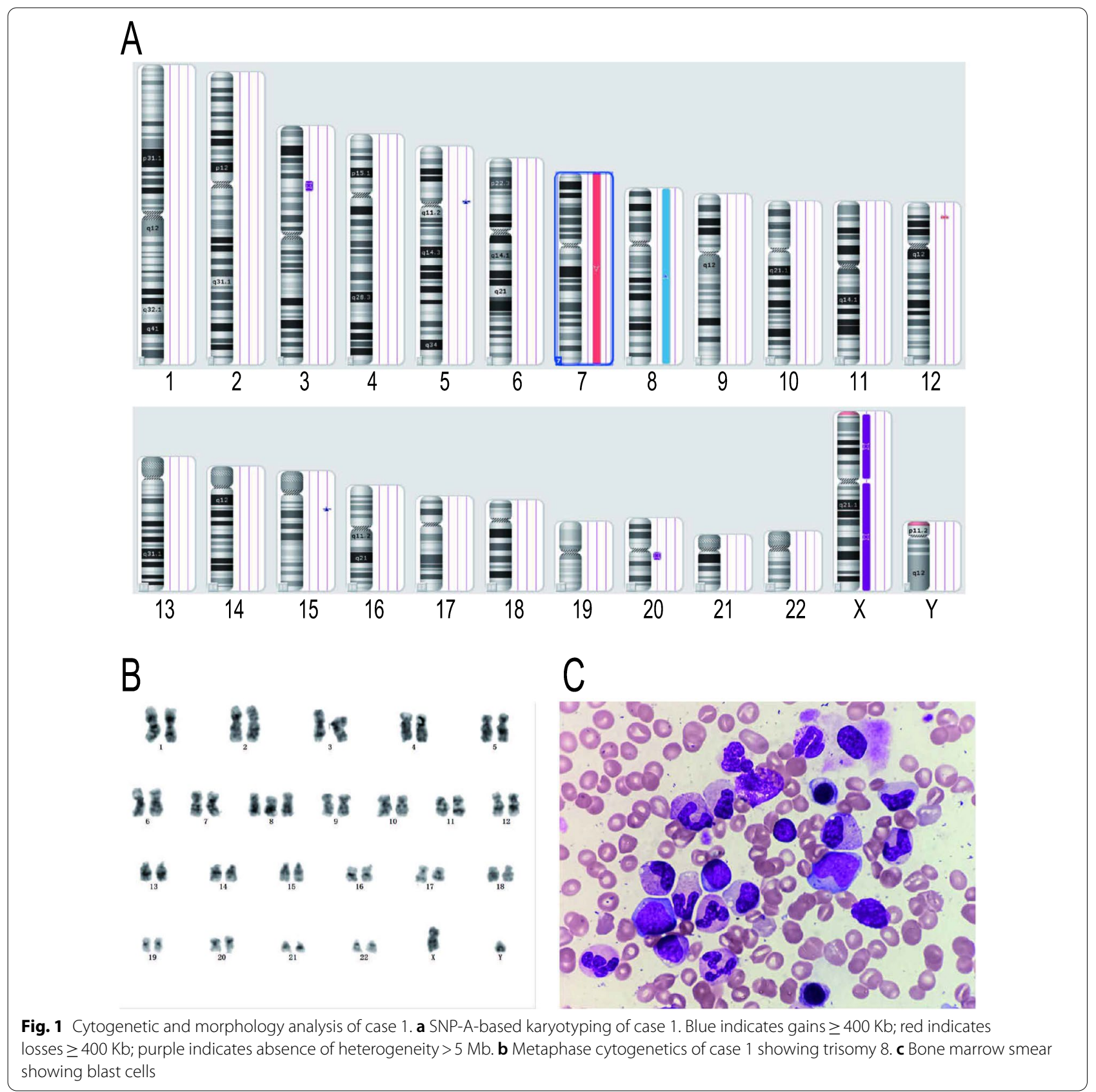

7 may affect the expression of the neutrophil migration gene located on the $7 q 22$ gene region. This impairs the migratory and chemotactic functions of neutrophils and may be related to blast infiltration of the pituitary gland in these patients [11, 12]. De la Chapelle et al. [12] reported that $44 \%$ of DI-AML cases were associated with $3 q$ alterations. DI-AML with $3 q 21 q 26$ is associated with thrombocytosis, hyperleukocytosis, morphological abnormalities of thrombopoiesis, and poor prognosis $[13,14]$. A 3q21q26 alteration was found in case 2, but none was found in the previous DI-MDS. Moreover, no 
Table 1 List of the SNP-A-based karyotyping findings for Case 1

\begin{tabular}{|c|c|c|c|c|}
\hline Chromosome abnormality & $\begin{array}{l}\text { Copy } \\
\text { number } \\
\text { state }\end{array}$ & Size (Kb) & Significance & Location \\
\hline LossMosaic (7p22.3-q36.3) × 1-2 & 1.5 & 159,076 & \multirow[t]{2}{*}{ Abnormalities in myeloid malignancies esp. in MDS } & $43,376-159,119,707$ \\
\hline GainMosaic $(8 p 23.3-q 24.3) \times 2-3$ & 2.3 & 145,471 & & $158,048-145,629,232$ \\
\hline LossMosaic (12p13. 2-p13.1) × 2-3 & 1.5 & 1,951 & Reported in MDS-RAEB2 & $11,197,813-13,148,969$ \\
\hline Gain(15q12.3) & 3 & 414 & Polymorphism in copy number variation & $32,029,692-32,444,043$ \\
\hline UPD (3p21.31-p21.1) & 2 & 8,455 & \multirow{3}{*}{$\begin{array}{l}\text { Reported in the normal human UPD database and no reports } \\
\text { in blood diseases with the acquired or constitutional UPDs* }\end{array}$} & $45,843,438-54,298,805$ \\
\hline UPD (20q11.21-q11.23) & 2 & 6,643 & & $29,501,306-36,153,360$ \\
\hline Gain (5p12p11) & 3 & 1,100 & & $45,288,800-46,389,261$ \\
\hline
\end{tabular}

UPD uniparental disomy

* Reference database: Liehr T. 2021. Cases with uniparentaldisomy. http://cs-tl.de/DB/CA/UPD/0-Start.html

thrombocytosis was found in case 2 as well. Whether $3 \mathrm{q}$ alterations plays a role in DI-MDS remains to be verified.

With similar cytogenetic abnormalities of chromosome 7, DI-MDS probably have poor prognosis as DI-AML [1, $8,15]$. In all three reported DI-MDS who did not perform allogeneic HSCT, progression to AML occurred within three months $[4,9,10]$. In case 2 , rapid progression to AML occurred despite being treated with decitabine. These results suggest that allogenic HSCT may be the only effective therapy for DI-MDS and should be performed as soon as possible. In all reported cases and our cases, the symptoms of polydipsia and polyuria could be controlled by desmopressin $[4,6,7,9,10]$. Desmopressin was no longer needed after MDS were well controlled in our case 1 and two reported cases $[6,9]$. The need for desmopressin, however, persisted even after allogenic HSCT in one case [7]. Both cases showed fluctuation in the severity of DI with MDS status. Thus, it would be worthwhile to investigate how the MDS status influences the incidence or severity of DI in the milieu of fewer blasts.

Cytogenetic aberrations have played important diagnostic, prognostic, and therapeutic roles in MDS. However, a "false normal karyotype" often occurs in MC analysis due to a lack of metaphase nuclei in MDS. FISH and SNP-A-based karyotyping do not rely on metaphase nuclei, while FISH is limited to the detection of the known lesions. SNP-A-based karyotyping can reveal unbalanced defects in as few as $10 \%$ of cells analyzed by MC or FISH [16], thus to identify cryptic abnormalities that are below the resolution of MC analysis. Meanwhile, SNP-A-based karyotyping can identify segmental uniparental disomy (UPD) that is undetectable by MC or FISH. Recently, Yang et al. reported that UPDs were an independent prognostic factor in patients with MDS and normal karyotype [17]. However, compared to metaphase cytogenetics, SNP-A karyotyping cannot detect balanced translocation and distinguish individual clones. Thus, it is an effective strategy to combine SNP-A karyotyping and MC. Makishima et al. revealed that SNP-A karyotyping combined with routine MC in MDS improved the cytogenetic detection of monosomy 7 , del (7q), del (5q), del (20q), and trisomy 8 [18], as illustrated clearly in our case 1.

In summary, DI-MDS is closely related to monosomy 7 and is very likely to progress to AML. Allogeneic HSCT might be the only effective treatment. The use of SNPA-based karyotyping is helpful to further elucidate the pathogenesis of DI- MDS. 


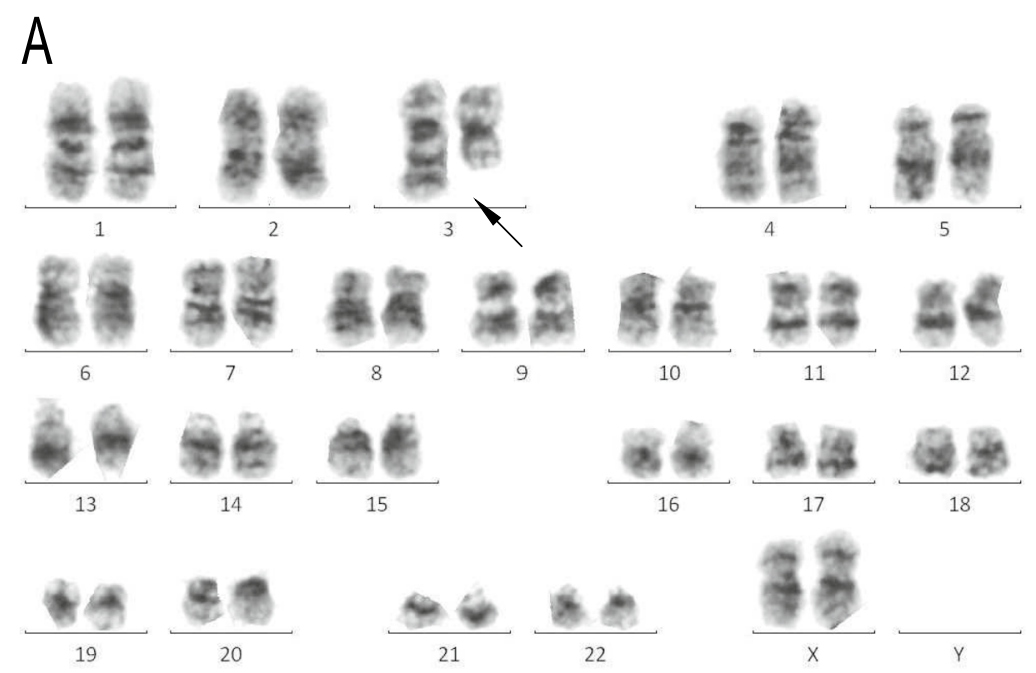

B

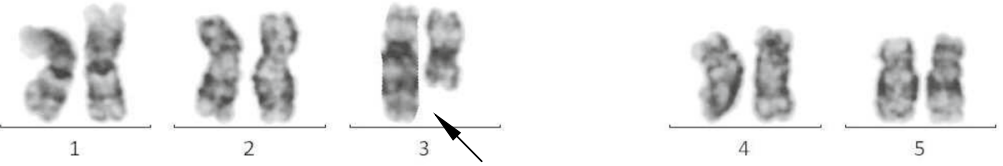

累解

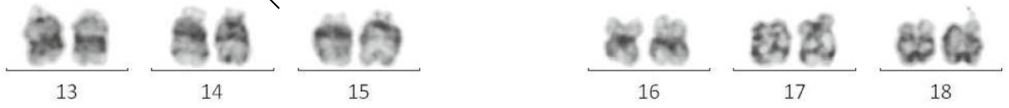

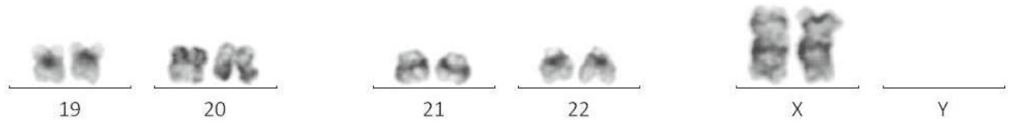

C

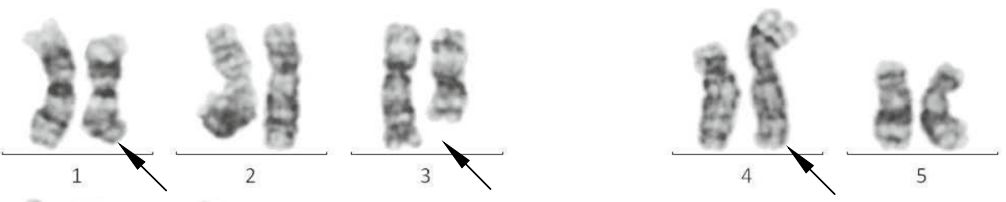

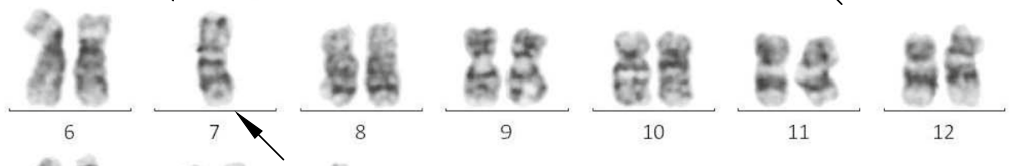

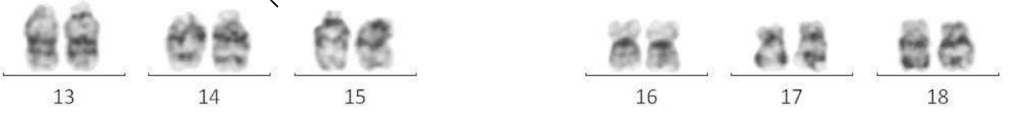

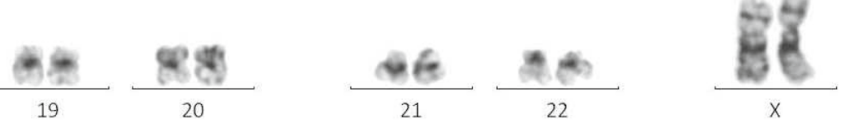

Fig. 2 Metaphase cytogenetics of case 2 revealed a karyotype including a 46,XX,t(3;3)(q21;q26), b 45,idem,-7 and c 45,idem,der(4)(1;4)(q25;p16),-7 
Table 2 Characteristics of five reported DI-MDS cases and the presented two cases

\begin{tabular}{|c|c|c|c|c|c|c|c|c|}
\hline Reference & Age (years) & MDS subtype & $\begin{array}{l}\text { Partial/complete } \\
\text { deletion of } \\
\text { chromosome } 7\end{array}$ & MRI abnormal & $\begin{array}{l}\text { Treatment of } \\
\text { MDS }\end{array}$ & Outcome of CDI & $\begin{array}{l}\text { Time } \\
\text { to AML } \\
\text { (months) }\end{array}$ & OS (months) \\
\hline Case 1 & 43 & RAEB1 & Yes & $\begin{array}{l}\text { A slightly thick- } \\
\text { ened pituitary } \\
\text { stalk and a small } \\
\text { nodule in the } \\
\text { left pituitary }\end{array}$ & Allo-HCT & $\begin{array}{l}\text { Controlled by } \\
\text { desmopressin } \\
\text { and cured after } \\
\text { HCT }\end{array}$ & No & $13+$ \\
\hline Case 2 & 40 & RAEB1 & Yes & No & $\begin{array}{l}\text { Decitabine and } \\
\text { Allo-HCT }\end{array}$ & $\begin{array}{l}\text { Controlled by } \\
\text { desmopres- } \\
\text { sin and HCT, } \\
\text { reappeared } \\
\text { when disease } \\
\text { progress }\end{array}$ & 2 & 11 \\
\hline 4 & 74 & RAEB 1 & Yes & No & Supportive care & $\begin{array}{l}\text { Controlled by } \\
\text { desmopressin }\end{array}$ & 2 & 2 \\
\hline 6 & 6 & RAEB 1 & Yes & No & Allo-HCT & $\begin{array}{l}\text { Controlled by } \\
\text { desmopressin } \\
\text { and cured after } \\
\text { HCT }\end{array}$ & No & NA \\
\hline 7 & 53 & RAEB 2 & $\begin{array}{l}\text { No (Norma karyo- } \\
\text { type) }\end{array}$ & $\begin{array}{l}\text { Nodular lesion on } \\
\text { pituitary stalk } \\
\text { \& absent of } \\
\text { posterior "bright } \\
\text { spot" of neuro- } \\
\text { hypophysis on } \\
\text { T1-weighed MRI }\end{array}$ & $\begin{array}{r}\text { Chemotherapy } \\
\text { and Allo-HCT }\end{array}$ & $\begin{array}{l}\text { Controlled by } \\
\text { desmopressin } \\
\text { and need for } \\
\text { desmopressin } \\
\text { persists after } \\
\text { allo-HCT }\end{array}$ & No & $18+$ \\
\hline 9 & 60 & MDS-MLD & $\begin{array}{l}\text { No (Norma karyo- } \\
\text { type) }\end{array}$ & $\begin{array}{l}\text { Attenuation of } \\
\text { "bright spot" }\end{array}$ & Chemotherapy & $\begin{array}{l}\text { Recovered after } \\
\text { chemotherapy }\end{array}$ & 1 & NA \\
\hline 10 & 73 & NA & Yes & $\begin{array}{l}\text { Absent of poste- } \\
\text { rior "bright spot" } \\
\text { \& symmetrical } \\
\text { enhancing } \\
\text { lesions in the } \\
\text { hypothalamus }\end{array}$ & NA & $\begin{array}{l}\text { Temporary } \\
\text { controlled by } \\
\text { desmopressin }\end{array}$ & 3 & 3 \\
\hline
\end{tabular}

MDS myelodysplastic syndrome, $C D I$ central diabetes insipidus, $M R I$ magnetic resonance imaging, NA not available, $A M L$ acute myeloid leukemia, $O S$ overall survival $R A E B$ refractory anemia with excess blasts, $A$ llo-HCT allogeneic hematopoietic cell transplant, MDS-MLD MDS with multilineage dysplasia

\section{Abbreviations}

ADH: Antidiuretic hormone; CDI: Central diabetes insipidus; MDS: Myelodysplastic syndrome; AML: Acute myeloid leukemia; MC: Metaphase cytogeneticS; SNP-A: Single-nucleotide polymorphism array; TSH: Thyroid-stimulating hormone; MRI: Magnetic resonance imaging; CBC: Complete blood count; WBC: White blood cell count; AOH: Absence of heterogeneity; MDS-EB1: MDS with excess blasts-1; HSCT: Hematopoietic stem cell transplantation; UPD: Uniparental disomy.

\section{Acknowledgements}

We would like to thank the patient for participating in this study.

\section{Authors' contributions}

Y.Y., Y.W., and T.L. prepared the manuscript, Y.Y., T.L., T.D., and Y.W. provided medical care to the patients. All authors provided revisions and feedback on the manuscript draft. All authors read and approved the final manuscript.

\section{Funding}

This project is supported by the Sichuan Provincial Academic and Technical Leadership Support Funding Project, (2018RZ0137).

\section{Availability of data and materials}

All relevant data and material is included in this publication.

\section{Declarations}

\section{Ethics approval and consent to participate}

This study was approved by the scientific ethical committee of our hospital. Informed consents were obtained from the first patient and husband of the second patient for publication of this case report and any accompanying images.

\section{Competing interests}

All authors have declare that they have no conflict of interest.

Received: 2 April 2021 Accepted: 7 Auqust 2021

Published online: 01 September 2021

\section{References}

1. Cull EH, Watts JM, Tallman MS, Kopp P, Frattini M, Rapaport F, Rampal R, Levine R, Altman JK. Acute myeloid leukemia presenting with panhypopituitarism or diabetes insipidus: a case series with molecular genetic analysis and review of the literature. Leuk Lymphoma. 2014;55:2125-9.

2. Dilek I, Uysal A, Demirer T, Koç H, Ozcan M, Keleş H, Numaoğlu N, Ustün C, Ciftçi E. Acute myeloblastic leukemia associated with hyperleukocytosis and diabetes insipidus. Leuk Lymphoma. 1998;30(657-60):3. 
3. Loukidis K, Papadakis E, Anagnostou N, Kiriklidou P, Gatsa E, Karagianni A, Patinakis P, Tsakiris D, Kioumi A, Korantzis I. Polyuria due to central diabetes insipidus presenting as an early manifestation of acute myeloid leukemia. Clin Adv Hematol Oncol. 2012;10:399-400.

4. Sun R, Wang C, Zhong X, Wu Y. Diabetes insipidus as an initial presentation of myelodysplastic syndrome: diagnosis with singlenucleotide polymorphism array-based karyotyping. Tohoku J Exp Med. 2016;238:305-10

5. Keung YK, Buss D, Powell BL, Pettenati M. Central diabetes insipidus and inv(3)(q21q26) and monosomy 7 in acute myeloid leukemia. Cancer Genet Cytogenet. 2002;136:78-81.

6. Kollen WJ, Ball LM, Snijder P, van Zelderen-Bhola SL, Egeler RM. Diabetes insipidus in a child with a monosomy-7 associated myelodysplastic syndrome and neurofibromatosis I. Med Pediatr Oncol. 2003;40:257-9.

7. Chuang C, Parnerkar V, Radulescu A, Hunt MA, Cayci Z, Ustun C. Diabetes insipidus in myelodysplastic syndrome: what we learnt from a case regarding its diagnosis, pathophysiology and management. Leuk Lymphoma. 2015;56:1134-6.

8. Harb A, Tan W, Wilding GE, Battiwalla M, Sait SNJ, Wang ES, Wetzler M. Acute myeloid leukemia and diabetes insipidus with monosomy 7. Cancer Genet Cytogenet. 2009;190:97-100.

9. Nakamura F, Kishimoto Y, Handa T, Arai Y, Mitani K. Myelodysplastic syndrome with central diabetes insipidus manifesting hypodipsic hypernatremia and dehydration. Am J Hematol. 2004;75:213-6.

10. Sano S, Yamagami K, Morikawa T, Yoshioka K. Myelodysplastic syndrome complicated by central diabetes insipidus and cerebral salt wasting syndrome with peculiar change in magnetic resonance images. Intern Med. 2010;49:161-5.

11. Ruutu P, Ruutu T, Repo H, Vuopio P, Timonen T, Kosunen TU, de la Chapelle A. Defective neutrophil migration in monosomy-7. Blood. 1981;58:739-45.

12. de la Chapelle A, Lahtinen R. Monosomy 7 predisposes to diabetes insipidus in leukaemia and myelodysplastic syndrome. Eur J Haematol. 1987;39:404-11.
13. Testoni N, Borsaru G, Martinelli G, Carboni C, Ruggeri D, Ottaviani E, Pelliconi S, Ricci P, Pastano R, Visani G, Zaccaria A, Tura S. 3q21 and 3q26 cytogenetic abnormalities in acute myeloblastic leukemia: biological and clinical features. Haematologica. 1999;84:690-4.

14. Lavabre-Bertrand T, Bourquard P, Chiesa J, Berthéas MF, Lefort G, Taïb J, Lavabre-Bertrand C, Navarro M, Bureau JP. Diabetes insipidus revealing acute myelogenous leukaemia with a high platelet count, monosomy 7 and abnormalities of chromosome 3: a new entity? Eur J Haematol. 2001;66:66-9.

15. Castagnola C, Morra E, Bernasconi P, Astori C, Santagostino A, Bernasconi C. Acute myeloid leukemia and diabetes insipidus: results in 5 patients. Acta Haematol. 1995;93:1-4.

16. Kolquist KA, Schultz RA, Furrow A, Brown TC, Han JY, Campbell LJ, Wall M, Slovak ML, Shaffer LG, Ballif BC. Microarray-based comparative genomic hybridization of cancer targets reveals novel, recurrent genetic aberrations in the myelodysplastic syndromes. Cancer Genet. 2011;204:603-28.

17. Ou Y, Yang Y, Yu H, Zhang X, Liu M, Wu Y. The prognostic significance of single-nucleotide polymorphism array-based whole-genome analysis and uniparental disomy in myelodysplastic syndrome. Int J Lab Hematol. 2021;00:1-8.

18. Makishima H, Rataul M, Gondek LP, Huh J, Cook JR, Theil KS, Sekeres MA, Kuczkowski E, O'Keefe C, Maciejewski JP. FISH and SNP-A karyotyping in myelodysplastic syndromes: improving cytogenetic detection of del(5q), monosomy 7, del(7q), trisomy 8 and del(20q). Leuk Res. 2010;34:447-53.

\section{Publisher's Note}

Springer Nature remains neutral with regard to jurisdictional claims in published maps and institutional affiliations.
Ready to submit your research? Choose BMC and benefit from:

- fast, convenient online submission

- thorough peer review by experienced researchers in your field

- rapid publication on acceptance

- support for research data, including large and complex data types

- gold Open Access which fosters wider collaboration and increased citations

- maximum visibility for your research: over $100 \mathrm{M}$ website views per year

At BMC, research is always in progress.

Learn more biomedcentral.com/submissions 